\title{
Leadership Research - Old Truths and New Frontiers. Notes on complexity and leadership in-situ.
}

\author{
Glenn Hultman, Phd, Professor \\ Department of Behavioural Science and Learning, \\ Linköping University, Sweden
}

What we know about leadership is recognized in a number of research reviews (eg Miller \& Rowan, 2006; Hattie, 2009; Yukl, 2009, 2013) and in research on "organizational learning" (Cohen \& Sproull, 1996), learning mini-worlds and knowledge domains (McLaughlin, 1998; Siskin, 1994), the new-institutional school (Powell \& DiMaggio, 1991) and research on organising and "sense making" (Weick, 1995) with an interest in the ambiguous and complex. One conclusion is common in some of these analyses and that is that researchers find it difficult to reach firm conclusions regarding definitions and reliable knowledge about leadership.

The numerous definitions of leadership that have been proposed appear to have little else in common than involving an influence process. Yukl (1989; 2013: 18, 389)

... these various definitions actually creates a great degree of uncertainty around what exactly leadership is. ... a puzzelment about what is meant by leadership and what is involved in leading. Spicer \& Alvesson (2010)

Within traditional management research there are a variety of studies, which have been recognized by, among others Yukl (1989; 2013), and in a meta-analysis of Backstrom, Granberg \& Wilhelmson (2008). Some researchers are not convinced that it is possible to draw general conclusions, they argue that the analyses are made with different starting points and in different cultures and that they are studying various aspects of leadership and thus sees different things, for example, the leaders style and stresses the difference between "leadership" and "managerial". Instruments may be imported from one environment to another without knowing if they fit into the new context. Yukl (1989) argues that his analysis nevertheless shows the available knowledge in the field. Recently, however, Yukl (2009) pointed out that the leader-led theories (dyads) might miss important influence processes. He calls for new models ("multi-level") and new perspectives on influence, leadership and learning in organizations (c.f. also Hannah \& Lester, 2009). One factor that interferes with our understanding of the phenomenon of leadership is that there are so many similar concepts. This has been called "adjective-plus leadership" (Robertson \& Timperley, 2011) and they present a plethora of concepts, for example authentic-, coaching-, distributed-, pedagogical-, strategic- and transformational leadership. Most of them are overlapping.

\section{Efficiency and scientific methods.}

A difficulty in efficiency studies, is that it sneaks in some methodological problems in presentations and when trying to make comparisons (Thrupp, 1999; Yukl, 2009). Yukl argues that survey techniques is not appropriate in all studies of leadership. It may be difficult to obtain statistically significant differences and then one will be dependant on what they think they see in the data. It is equally interesting if it turns out that there appears no difference between successful and less successful principals and schools.

Hattie (2009), in his meta-analyses, demonstrated that there is a statistical relationship between certain type of leadership (instructional) and student outcomes. But he notes that this relationship does not automatically mean that we have a cause-effect relationship. He points out that there are interaction effects that probably are the most important. It seems that some 
successful systems, for example, Ontarios' (Canada) strategies in school development, uses that approach (Fullan, 2011).

In quantitative analyses presented by e.g. Miller \& Rowan (2006) in which they analyse an extensive data set, the database can provide a measure of things like supportive leadership, teacher autonomy and teacher collaboration ("organic management") and its effects on pupil performance. They found almost no correlation between this type of "management" and results. They believe that one should look for other important factors that may contribute with an understanding of what affects pupil performance.

As if the above were not enough to create confusion Grissom \& Loeb (2011) presents a quantitative analysis of principals' efficiency showing that only one factor, "organization management skills", predicts the development of student performance and other factors of success. This factor involves work with resources, budget, school work environment and handling of urgent questions for teachers (p. 1101). The researchers point out that this is traditional management but nevertheless clearly related to the work of teachers.

\section{How to think and analyse?}

Future studies can deepen our understanding of the complex environment in which managers work is moulded and practiced. In focus will be leadership and managerial position at different levels and how these interact and managers prerequisites to exercise leadership. This interest has much in common with what is termed "distributed leadership" (Spillane et al, 2011) with a focus on increasing our understanding of the interaction that takes place in an organization. And then this may include shortcomings in what is distributed or a distribution that looks completely different than the desired or that "distributed" means a situation in which leaders do not harmonise.

In different analyses one can see that the observations of principals' work is very similar, although over time (e.g. Hultman, 1998; br Sundin, 2007 and Presthus, 2010), but the researchers choose to "see" different dimensions of this complex work. Here, the choice of method can be important. Are different researchers using observations of the work or what is said in focus interviews or the principal's rhetoric or what the teachers say in interviews or is it the researcher's impressions and interpretations that dominate conclusions? In previous studies it has been shown that, for example, teachers only see 40 per cent of a principals actions (Hultman, 1998), and that may result in a limited picture of what goes on. In the aforementioned study by Presthus (2010), one sees clearly the principal's involvement in meetings, conversations and how they "move around in the school" Her ambition is to understand how their instructional leadership plays out and what she defines as "small talk" strategies (compare Hultman, 2010) and the function of the latter is relationship-building, navigating (giving other actors a new focus), provides insights into the school culture, creating invitations to interactions but also provides space to influence and manipulate. In Thomson's (2009) report she reveals that observations of the principal's job is equal over time, for example if you compare Wolcott (1973) and Presthus (2010), but she believes that a significant amount of administration has been added. Then you could say that it is certain work that is added on top of the "normal" work as leaders: extra administration, demands for certain types of leadership style, demands for improved pupil achievement and so on. Thomson argues that the intensity of work has increased as did Hultman (1998).

\section{The "invisible" dynamics of leadership.}

In many studies of principals work a comprehensive picture of work activities is presented. Especially in ethnographic studies and initiated field studies over quite a long time. Despite 
these we are lacking insight into the difficult and problematic sides of their work, "the ugly side of leadership" (c.f. Thomson, 2009) showing that side of leadership which, among other things, puts the leader in a situation where they do not really understand why things happen or where they feel that they can not establish the necessary relation with some of their employees. But they are still formal heads and they have to make wise decisions. In an analysis reported by Thomson (2009) she reveals a different side of principals' work, it's not the happy, healthy and successful actors that is presented. She highlights the side of the job, involving issues of a sensitive nature, for example, to give a teacher negative feedback. Thomson (2009) points out that the instructional leadership required of a leader can mean the one is perceived as an internal inspector instead of a resource and partner in the dialogue if the requirement is to exercise direct control of the teacher. The perspective is important for understanding the dynamics of leadership and to some extent mitigate the dominant image of the leader as heroic and efforts to create successful schools.

\section{Research on school leaders work and leadership.}

Previous research focused on leadership (leader - led) rather than the manager's work patterns. This meant that some aspects of managerial work was highlighted more than others. Studies of managers in industry are many and they have been the subject of systematic reviews (e.g. Mintzberg, 1973; Hale, 1986) and within schools (Bridges, 1982; Hultman, 1998).

Pitner (1982) reviewed some of the studies using observations about what leaders do and she showed a number of common characteristics. They spend for example, very little time on what happens in the classroom, which is a topical issue today. In recent years, a number of observational analyses has been presented e.g. Brüde Sundin (2009).

Holmberg \& Tyrstrup (2008) notes that managers express "... guilty conscience - they think they should spend more time on some matters. They feel that they do not have time to engage in any 'real' leadership. They do not feel comfortable, and their impression of everyday actions as a result of poor leadership." I have encountered similar reactions among the principals we folowed and I also see the gap between management ideals and reality in various settings (Ludvigsson, 2009). A general feture that can be noted is that the organizational levels seem to be loosely coupled.

\section{Managerial work and leadership in different organizational domains.}

An important perspectives on leadership can be identified when focusing on complex organizations. One can for instance think about dyads, i.e. the interaction between managers on the same or different levels. And these dyads can be perceived as a game of negotiations between different organizations in the same organization. This can also be deepened if we look at triads (managers in different domains) or multiple interactions. It then becomes an interest in management systems and multiple cultures and not only a focus on individual positions. We are interested in the "whole" hierarchy and refraction of different levels. Here, a comparison can be made with the study of Hultman \& Wedin (2004) and Hultman (2008) analysing the interaction between politicians, officials and principals (triads). This managerial interaction has not been studied in this way to any great extent before. Some researchers, for example Sahlin - Andersson (1999) and Hultman (1998, 2001) have studied aspects of the system and aspects of triads. Hultman, for example, has analysed the part of the system that includes principals and teachers (c.f. Ludvigsson, 2009), Nespor (1997) the interaction between schools and their surroundings. In a study of school superintendents (Nihlfors, 2003) their contacts, where some of these are described in process terms (interaction and dialogue). 
It may be fruitful to understand an actor's learning and meaning making in the context of the complex system that the school and the municipality forms, where the actor is part of a system that includes the other actors. Thus is created a complex system of meaning making processes (cf. Seashore Louise, 2010), which in this case can be interpreted in terms of leadership and managerial actions. The system can be studied in terms of relationships, negotiation and loose couplings as an expression of the interaction between different genuine cultures, i.e., their ideals, values, traditions and work environment. It is about this system we need in-depth knowledge, to generate understandings of managerial work and leadership in such organizations.

Hultman (1998) has suggested that it might be fruitful to see leadership as the art of leading those who lead themselves. And these relations are the most central fields in the interaction between the nodes in the system where policy, learning and leadership is enacted. In each node of the organizational network is the actor and manager inside their culture with a work situation that can be characterized by the expression: social ambiguity and multiple steering impulses (not only official goals). The actor is living in a flora of logics that creates a different kind of rationality than we usually perceive as correct. A contextual rationality as a basis for leadership actions.

\section{Leadership and learning.}

Some researchers discuss the relationship between leadership and pupil learning, (Robertson \& Timperley, 2011) with different perceptions of leadership and the link to pupil achievement. There is also another perspective, highlighting learning in the everyday lives of the various actors in the system (Hultman, 2008), especially for those who are leaders. One can also assume that in reality a very autonomous leadership may be involved for the individual actor, with loose couplings to the other. At the same time actors are included in a common system, which consists of the municipality and the political system. Here you can talk about being each others conditions. The various actors have to deal with these double "relationships", which Siskin (1994) calls "embeddidness" and "relatedness".

A distributed perspective (Spillane et al, 2011) also discusses learning in the system and often in terms of a common learning and access to new information. Then strong ties becomes important but I think we also have to take into account the everyday work and the existence of weak ties (Weick, 1995). Spillane et al argue that strong internal and external relationships have a positive connection with pupil achievement as it increases the flow of new ideas, which in turn can affect teaching. One can thus include other way to discover leadership and learning and how knowledge can be created in different ways. Based on Hultman (2004), one can imagine different forms: no learning which means some changes going unheeded; firstorder learning which involves change within established frames and conditions; second-order learning which involves a questioning of frames, approaches and principles; third-order - or meta-learning, where one learns something that is not on "the agenda". This may mean that you either learn something that is understood as important e.g. "a local organization theory" (mental map) or "learning - to - learn" (process insights), or that one learns something about power structures, ones own competence etc. and/or symbolic learning, which means that you behave as if you learned something new or talk as if the new is implemented, even though things stays the same. Regarding the relationship between learning and acting, I perceive that learning can either be the result of a conscious influence, for example an effort to bring about a "learning organization" in schools or as a result of more unplanned acts giving rise to various forms of learning.

The classical leadership and management research (Yukl, 1989) needs to be expanded inspired by "new" institutional theory, ethnography/ethnomethodology and complexity theory. 
Ogawa et al (2008) argue for a rapprochement between research on learning, organizational and institutional theory. One can understand the interplay between levels in various ways either a net in harmony or system in terms of loyalties (Hultman, 1998, 2001), trust relationships or parallel discourses (Hultman \& Wedin, 2004)?

What knowledge can be generated about managerial leadership in organizations if we see levels that do not "stick together" although they constitute a system? In the classic leadership research (Yukl, 1989) and theories from "observational studies of managers" (Hultman, 1998) there are analyses of interest: mutual-trust theory, instead-of-leadership theories, grassroots bureaucracy theory, micro-political actors, zone theories and theories of meaningmaking actors (in order Yukl, 1989; Kerr \& Jermir, 1978; Crowson \& Porter Gehrie, 1980; Cohen \& March, 1974; Peterson, 1984; Willis, 1980 and Pitner \& Ogawa, 1981). There are an interest in these issues in activity theory (Engeström, 1996) and in actor-network-theory (Nespor, 1994; Czarniawska \& Hernes, 2005), but with a focus on slightly different aspects. In models for distributed leadership (Spillane, 2006) the focus is changed "... focus from school principals ... to the web of leaders, followers, and their situations that gives form to leadership practices", and the idea of leadership in terms of interaction between actors.

Holmberg \& Tyrstrup (2008: 100) argues that "knowledge is created in the gaps in the organization ... It is in the interplay and interaction that new knowledge is produced." Added to this "leadership" is created in the interaction, or as Holmberg \& Tyrstrup puts it, "Every little incident and "fire fighting' will actually be an opportunity to exercise leadership ...," as in schools and public organizations (Hultman, 1998, 2008; Moqvist, 2005; br Sundin, 2007; Ludvigsson, 2009).

\section{Leadership as process}

In light of the above account, I see leadership as a process (Yukl, 1989), but a process that is not unidirectional. Many of the definitions that have been presented over the years (cf. Backstrom, Granberg \& Wilhelmson, 2008) is a directed relationship (arrow goes from the leader to the led) with severe steering, goal orinentation and power. One can stay open as to who has power over whom. But still it is about an interaction between two or more people and it is a process with ambitions to influence others. A unidirectional definition may cause us to overlook important relationships and loose couplings in interaction.

According to some researchers (Hultman, 1998, 2008; Moqvist, 2005; br Sundin, 2007), the definition of leadership becomes the relationship itself and it is created, established and maintained by the meetings and interactions that occur in the environment or between the nodes. The relationship refer to a reciprocal relationship with some kind of exchange. It builds up and can hold mutual trust, but the relationship can sometimes become unequal and based on the exercise of power. Leadership is not established if either party refrains from recognizing leadership. At the same time, a relationship between manager and employee may exist formally, which becomes important to pay attention to and a manager's problematic aspects in work, such as when the leadership is inhibited and only the formal relationship remains.

To get closer to the process that portrays leadership and knowledge transfer in an intimate setting, I refer to a study that was conducted to increase understanding of coaching and how professionalism is transferred from the teacher (who has the mission as a mentor) to the student teachers (Hultman \& Wedin , 2014). We followed the interaction and conversation between teachers and students. This dynamic is similar to what Huberman early termed "sustained interactivity" (Huberman in Seashore Louise, 2010) when he discussed the interaction between researchers and practitioners. The mentor's strategies to help the students into the teaching profession was characterized by "nearness" and others have used the term "at the elbows." The strategies are characterized by the work being done together in the planning and 
work in class and a reason for this may be that the interaction takes place in a complex situation and that much of the content consists of tacit knowledge. In the latter case in the form of silent actions, that is understood better if you look at them in the situation and can talk about what is happening directly adjacent to what is done (Eraut, 2010). An example of a strategy without nearness may be that the mentor completely lets the student plan and take the class itself and then discuss what happened a few days later.

The mentor's strategies is that they comment, critiques and give positive feedback in the direct connection to the lesson implementation. They plan together but also allows students to have the opportunity to introduce their own ambitions. The mentor puts himself in a position where she may provide an alternative interpretation of the situation, such as the student may perceive as negative can have a positive side. This strategy is similar to that in sports where a coach transfers an alternative interpretation of what the athlete does. The mentor also provides "research missions" and encourages didactic test and is present to see what happens. In such situations and in everyday work mentor takes up a conversation and an analysis of the dynamics of the class. This interaction can be seen as an illustration of leadership and can say something about the dynamics of transmission between the teacher and the student. This leadership is studied in situ and characterized by relationships and knowledge creation. Henceforth illustrated how the leadership and the interaction portrayed when players talk about what happened earlier in the day.

The mentor tries in their work and in conversations to contribute their experiences to create an understanding of the nuances that are at work. Sometimes it is the mentor (M) who contribute with an example or choose an episode. Other times it may be students (S) who break in with their impressions, shown in the vignettes below.

(M) So ... that's all that sort of thing, you need to take with a pinch of salt because you do just what is possible. They want, most of the time, just check and see where they've got you, they are testing us all every day, it's nothing strange in that.

(S) Yes.

(M) We are, after all, their testing area.

(S) Yes you can see that when they enter the classroom.

(M) Yes, if he's OK or not, you can see that at once.

(S) Yes

Here one can perceive a leadership that seeks to both transmit tacit knowledge and that a given situation can be understood in different ways. In the first vignette the tutor is using her own experiences to contribute a nuanced picture and to play down what could be perceived as problematic. Pupils' behaviour can mean different things that you need to understand. I perceive that the leader is trying to transfer and teach "the art of seeing" or to "read" situations. And in the learning process she is using episodes taken from the work in class earlier in the day. [this connection and interpretation was possible because sometimes we conducted participant observation before our participation in their conversations].

In the next vignette the leader gives a positive judgment as she contributes with an explanation of what happens in the situation.

(M) And I think they listen to you and so, that feels good.

(M) Yes that half of the class knew you and then the others felt that it was safe

(S) Well, they know her ...

(M) If someone had said "Öhh here comes Eva" heck you don't know what could had happened, yes, but then it's like that, one influences each other in life and it happens to children too ...

(S) Yes, agree ...

6 SocArxiv, 2018-03-15 
This sequence illustrates how the leader is trying to convey an explanation of how the local network in the class works. How a system works in terms of trust and confidence and how it is spread in the group. I interpret this to mean that the leader wants to demonstrate that teachers not only leads individuals but a system. And this means that you need to understand the idea of being both a part of the class and the system and at the same time being outside. The lesson is that, as the leader, you are both in the situation and holding a distance to it. The mentor may, in such cases, as here, add a hint of an alternative, a presumptive negative situation. The student's responses can be interpreted as an understanding of what the leader tells him, which is demonstrated clearly in what later made into concrete action in the classroom.

The mentor can use concrete examples to create an understanding of the interaction between individual students and the class as a whole. How this is both enter state while providing the effects on the class.

(S) But I thought it was really nice to be there and listen because then I know myself how I should respond to pupils or what I can expect.

(M) Yes. And this girl Moa then, she will come to you when she is ready and it is just that you are yourself and you're like thee with her. Have a rather quiet way with her, and then you have others that will test you like hell.

(S) They has already begun. Today, when they would start with the name signs, he said immediately like this "yes, but we can change signs, you and I, so we deceive her," and so I went up and said "yes, but it's no use, I already know your name, I learned it pretty soon your names"...

(M) And then really, really be nice to Moa there, because Moa has not fallen behind in math right now and it's great for her - when she feels that it is hopeless - she gives up completely, then there is nothing to come back to so it's much appreciated that you can approach her and emphasize "now I take you Moa a while and the rest of you, you have to ask each other or help each other and so" - you hold this yourself and so, you give her that. For as I said ... I can not let her slip back now so I said come now and I'll work with you ...

The leader sees a situation that can be used to point out an important aspect of the work, for example, that you get the advice to take on a student. Perhaps one can sense that this gives a positive signal "a good behaviour from the leader" as noted by the other pupils. And then this is accepted by the rest and they keep working on. Next time, positive actions can apply to someone else in class.

An important action from the leader is to clarify what happens in everyday life and how it can be understood in different ways.

(M) Yes, but that was good ... and what a relief that you did your own thing for that is what is happening, you plan so well and you think that it will work and so on, and then as you say, oh well when you noticed that half the group did not do what they should or whatever it was and then you decide to find another kind of ending that still worked for you and for the class. And I think it's good that you can be so flexible enough and do not feel, no I'll need to do this ending ...

(S): Then I try not to be too planned - because I think it is not good because then you will be enough ... will be to planned for ... and can not get away from my planning.

(S) There is so much that you can not influence and that happens no matter what you have planned and how well you feel that you have planned the day, so that kind of stuff happens anyway, that we can't influence, but we still have to do something about it.

In this case, it is a plan that is not working as it was intended. This could be perceived as somewhat problematic but the leader can with his experience argue that there are different dimensions of work and the dynamics of the class. It may be perceived as something negative but can also be perceived as something good, namely to act in a flexible manner. Behaviour in complex environments do not always follow the plan, because there is another dynamic that one needs to understand. In other situations, the leader may argue that it is important to be 
well prepared to anticipate the chaos that one may perceive and this means that she teach that a leadership action is initiated, so to speak, before an event occurs. Some classes can not be left alone before, for example, one had time to establish a trust relationship that makes the class self-sustaining in some situations. In the second quotation, one can perceive that the student demonstrates an understanding in terms of complexity, demonstrating that he really want to get into "chaos", because it provides a strategically important knowledge.

In the third quote it's about flexibility but also the realization that the environment is characterized by ambiguity and very irregularity. The leader can teach the art of leading in a situation that sometimes appears to be "difficult to manage".

The mentor can also identify good leadership shown by the student and pay attention to such a sequence.

S) Yes, because I thought it was so nice and sit with them so it became much, much closer and they, there was no one who could disappear behind somebody else ...

(M) No.

(S) ... and all of them was visible and was included. It became a different ...

(M) Circle, yes

(S) ... community when we sat like that.

Here, it is the student who tell about things that occurred and the leader can reinforce good leadership in what is reported or from what happens at work during the day.

It also happens that they specifically talk about leadership in their conversations.

(M) Leadership style, think about the leadership style that suits you best - I'm curious, what do you feel most comfortable with when you ...

(S) I want to be nice but it's hard with these kids, to be kind.

(M) Yes but excuse me, but it's so nice to hear that ... "I want to be nice." Because we - Jenny said today [colleague who was stand-in] "God, I feel like a nag, I just nags and nags" ...

(S) Yes, but that's it, I'm just Miss Angry throughout the day, it feels like I just - I shout and say "do not do that, do not do that, do not do that" and so they makes a good thing "yes, good" and then again "do not do that, do not do that" and it's not funny.

(M) Well, no, but just the feeling that you feel it, but you should also know that this is how we feel in our profession. You feel that God, the only thing I do is nag and nag ...

Here, leadership style is given a somewhat different formulation than in the traditional style of leadership research. At the same time, one can see similarities to a human- and relationship-oriented style. This example also illustrates the situational leadership theory with different styles (in this case, kind- and nagging style) affected by the dynamics of the class. People want to have one style but may be forced into another. The conversations do not use references to the concepts used within leadership research. The mentor also remarks that this is a common feeling among experienced teachers. A feeling that you are doing wrong can be shared by others and appear to be a common feeling, it's part of the work to feel this way. Novice ambition meets reality in the work situation.

Sometimes the mentor use metaphors [my note] in her language to convey an insight.

(M) It's a big part of the thing, I think, that you ... are confident in yourself because the kids have antennas, they feel immideatly.

(S) Yes, but it is ...

(M) They "reads" incredibly fast ... so it is important. But you're a person who is confident in yourself and I mean it affects them too.

(S) Yes, it does, it is obvious that it is visible ...

The use of the metaphor "antennas" can easily convey how the group reacts to a teacher's actions. It is the teacher's attitude and "style" and the attitude that students feel. One can imagine 
that the leader wants to convey that it is not just teaching content that is important. And the students seem to signal that he noticed that feeling.

One can also note that the mentor sometimes teaches the principle of "lead by gut feeling".

(M) Either one feels that "yes, I have time to walk around, it's okay that I do it" or that you feel that "no, it's twenty pupils asking the same thing, I break, put down the pen, jointly explains, and go on ...

One captures the mood of the group, an immediate sense, an intuitive decisions in the moment.

The mentor can also take advantage of situations to both provide strong reinforcement and illustrate aspects of successful leadership.

(M) So, it is quite bravely done, I think, in the beginning of your career but, I know that you are confident in this with groups and leadership, and you dare ... there is no danger that they are chattering and talking because you are so confident or you know you can take them back. There are students who might be terrified of such a situation because they think they're losing it completely.

(S) It has not even occurred to me, that thought, to be honest.

(M) No, I understand that, and I see that it is so ... and that's a strength that you can do it, that you dare, because one have to take the risk.

(S) Mm, it was fun

(M) Mm, you trust that you can take back the leadership when you decide that you are ready. It's pretty interesting too when you release them to a discussion, one can almost hear when it's time to end discussion, I do not know if you are conscious about it, I am. At first, it is a little bit cautious ...

(M) ... and then it rises again and then fall again. And I tend to reflect about - when it falls the third time ... then talking is usually finished and it might be about right to break. Only by listening one can understand when it's the right moment.

In this vignette, one can see different aspects of leadership that are formulated in terms of "we are confident", "one dares", "take back leadership" and that they physically can "hear" when it is suitable to take it back. In the sequence above, the student expresses, in continuing the conversation that he had not previously thought of it this way, while he recognizes the dynamics. An important dimension of leadership is to be clear and at the same time pay attention to relationships in the interaction with the class.

(M) You've been thinking about what to say and how to instruct in class, and then you say, "I want" I like that, it's leadership, that I really like, I nag ...

(M) If you thought about it, during Math, I went around to every one and asked "how is it, how does it work, how's it going?", and I did it because I felt that I need to talk to all of them.

(S) But then you get, you even create a picture of where they are, you can see, as well, can look in the book, now he has reached this far and well ...

(M) And there may be someone who asks for some help and so on. Sometimes to feel confirmed but sometimes because they need the help.

(S) Mm, that's a great way to do it.

(M) It's good that you listen to them and try to sort out their issues, you do that well, they feel affirmed when you do, "he really cares about what we think and feel," and I think that's the key to getting a good pupil relationship, that they feel that you are listening to them for real, because it matters what they think and feel, it's really important to take up their suggestions and not just giving them what we as adults think and feel - interacting with them all the time. But that's also what makes the work dynamic.

(S): That's what's so funny too.

The mentor discuss and identify important aspects of leadership that is characterized by appearing as an authority, improve relationships and "see" the pupils as well as listening to them. This leader observe and discuss relationships and network in the micro environment. It becomes, so to speak, something they do together. A form of shared leadership (distributed 
leadership) where one perceives that "leadership" is not only a position but a relation and a transaction. And that the pupil is an actor, a didactic actor.

In some parts of the conversation they will be right in on the same concepts used in traditional leadership research, in this case a discussion about mutual trust.

(S): If you have the social capital in relation to the pupils, you can make a fools of yourself, then you can have a bad day. You can be tired.

(M); One can explain to them - I have a bad day today, it is best that you lay low. OK.

(S): Fine.

(M): I could not speak [throat infection], I wrote on the whiteboard, they came up to me and I was writing, it worked. And it is quite incredible. It takes time to build relationships and it takes time to create trust that you need.

(M) Then you draw your own line when you work, wherever you are, because this is all about my working environment and theirs. But the hardest thing, I think, is to get them to take responsibility when I'm absent ...

This can be perceived with the metaphor of "the art of leading those who lead themselves" for leadership in complex environments. A relationship that is built up over time and that is necessary in order to be able to carry out the instruction. A leader can use this capital when unpopular decisions must be made.

(M) I think, after all ... you have to be like you want your class to become, in some way, you have to be interested yourself and you need to show an interest and you have to ...

(S) It, of course, infects if you yourself are talking about that this is awesome and cool so just that could give a little ...

A model - the mentor teach that it is important to practice what you preach. You learn to work and understand the dynamics. And your approach and attitude affect students.

When analysing this type of work, teachers' work, different concepts emerges compared to those in the traditional leadership research. We study leaders who are not traditional managers. At the same time we can see that some concepts and descriptions agrees well with traditional concepts. The analysis and the above comments make visible theories such as situational leadership and mutual-trust theory. This environment will then interact with other environments in the school where there are both colleagues and formal managers and principals. We need deeper knowledge of leadership within and between environments.

\section{Leadership - science or practice?}

The research can focus on the interaction between different traditions and cultures. The interaction between, for example, principals and teachers are highlighted in the studies concerned with distributed leadership but this can be extended in analyses focusing on how the internal interaction manifests itself in other situations. The reported data above illustrates how the leader's actions plat out in a teacher's perspective with the interaction between teachers and students. In my data were the impressions of the interaction between mentor (teacher) and student teachers and their joint learning about the work and the dynamics of the class. One can perceive what is happening in this situation as leadership training in situ. This research is to some extent similar to research from observations of principals because you analyse all aspects of the working environment for them where both the nature of work and leadership is included.

The transition between domains and levels need not be perceived as onesided and hierarchical, but be perceived as an arena for negotiations or exchange relationships. With negotia- 
tions, I mean an exchange of steering signals, perceptions, knowledge and ambitions, between the players in this arena. Others have used metaphors like game, "games" (Lindensjö \& Lundgren, 1986; Firestone, 1989). The latter speaks of "Ecology of Games" and refers to the various games as part of a system, which can be interesting in an analysis of the relationship between different environments, for example, the teacher (as mentioned above) and the principal. One can base an analysis on the content (the exchange and interaction between actors and subcultures) in terms of interaction, learning and legitimation (Firestone, Fitz \& Broadfoot, 1999).

Yukl (2009) is hesitant to further develop the survey methodology in the study of leadership and organizational learning. He is seeking alternative methods e.g. single case studies over time or comparative analyses of several organizations. My experiences is in the same direction as this the phenomenon is not adequately studied for us to be able to construct good and theoretically relevant questions that can be answered by a large number of informants. In addition, teachers' leadership should be analysed in more detail.

Theories of leadership and learning, which should be used in the analysis assumes that knowledge, in large part, is something contextually, intertwined in our everyday work. Man is active and creates largely their own knowledge, it is not something that is received passively. It is important with a focus on the meaning making and interaction. Moreover, humans in their learning depends on the situation; duties as such, colleagues, students, professionals tradition, community spirit and perceived frame factors. For the teacher, it is also interesting to note the importance of personal theories (Hultman, 1998, 2015; Timperley, 2007, 2013) and how they are created.

As shown in this article, the research provides mixed messages about what is successful. But we can also take advantage of other studies, than evidence-analyses, which contributes to a deeper understanding of leadership dynamics. Researchers have pointed out that many competent leaders have inspired researchers to ideas and concepts about leadership (cf. Seashore Louise, 2010; Hultman, 2015), i.e. practice can influence the research, which in turn is disseminated back to practice. Leadership is above all proven experience. There is much in a leader's professional expertise that is difficult to codify and categorize and very situationbound. One learns leadership in practice and it is shaped by different situations and in that sense one can say that it is a form of apprenticeship - one becomes an apprentice-in-context (Hultman, 2011), as implied by the data presented earlier.

There is a risk that we focus too much effort on a certain type of efficiency. Efficiency can be interpreted in different ways depending on the logic that prevails. One can ask for metastudies such as Hattie but this type of analysis is not easily translate into practical action (Hultman, 2015), as he himself points out. An exciting interpretation of "scientific" is to systematically introduce everyday conversations and analysis in schools on the basis of what is happening in the school class. There is a rich source of knowledge (Hultman, 2001b, 2006, 2008) in the school's own day to day activities as illustrated above. A source that is not always fully utilized. And in these conversations principals have different roles, often as an instructional leader participating in conversations with teachers. And in these conversations various types of research might have a role in supporting development and we need to find ways for collaboration between researchers and schools.

\section{References}

Backström, T., Granberg, O. \& Wilhelmson, L. (2008). Alternativa former av ledarskap - en kunskapsöversikt om chefers ledarskap. I Döös, M. \& Waldenström, K. (red). Chefsskapets former och resultat. Två kunskapsöversikter om arbetsplatsens ledarskap. VINNOVA-rapport VR 2008: 15.

Bridges, E.M. (1982). Research on the School Administrator: The State of the Art, 1967-1980. 
Educational Administration Quarterly, Vol.18, No.3, pp. 12-33.

Brüde Sundin, J. (2007). En riktig rektor. Om ledarskap, genus och skolkulturer. Diss. Linköping Studies in Pedagogic practices No. 3. Linköpings universitet.

Carlson, S. (1951) Executive Behaviour. Stockholm: Strömbergs.

Cohen, M. D. \& March, J .G. (1974). Leadership and Ambiguity. The American College President. New York: McGraw-Hill Book Co.

Cohen, M. D. \& Sproull, L. S. (Ed.) (1996). Organizational Learning. Thousand Oaks: SAGE Publ.

Crowson, R. L. \& Porter-Gehrie ,C. (1980). The Discretionary Behavior of Principals in Large-City Schools.Educational Administration Quarterly, Vol. 16, No.1, pp 45-69.

Czarniawska, B. \& Hernes, T. (Eds.) (2005). Actor-Network theory and Organizing. Copenhagen: Liber \& Copenhagen Business School Press.

Engeström, Y. (1996). Development work research as educational research: looking ten years back and into the zone of proximal development. Nordisk pedagogik, Vol. 16, No. 3, s. 131-143.

Eraut, M. 2010. Knowledge, working practices, and learning. In Billet, S. (Ed). Learning through practice. Models, Traditions, orientations and approaches. New York: Springer Science and Business Media.

Firestone, W. A. (1989). Educational Policy as an Ecology of Games. Educational Researcher, Vol. 18, No. 7, pp. 18-24.

Firestone, W. A., Fitz, J. \& Broadfoot, P. (1999) Power, Learning, and Legitimation: Assessment Implementation Across Levels in the United States and the United Kingdom. American Educational Research Journal. Winter, Vol. 36, No. 4, pp. 759-793.

Fullan, M. (2011). Change leader. Learning to do what matters most. San Francisco: Jossey Bass.

Grissom, J. A. \& Loeb, S. (2011). Triangulating principal effectiveness: how perspectives of parents, teachers, and assistant principals identify the central importance of managerial skills. American Educational Research Journal, Vol. 48, No. 5, pp. 1091-1123.

Hales,C.P. (1986). What Do Managers Do? A Critical Review of the Evidence. Journal of Management Studies, Vol. 23, No.1, pp. 88-115.

Hannah, S.T. \& Lester, P. B. (2009). A multilevel approach to building and leading learning organizations. The Leadership Quarterly, 20, pp. 34-48.

Hargreaves, A. \& Fink, D. (2008). Hållbart ledarskap i skolan. Lund: Studentlitteratur.

Hattie, J. (2009). Visible learning. A synthesis of over 800 meta-analyses relating to achievment. London:

Routledge.

Holmberg, I. \& Tyrstrup, M. (2008). Att leda på gehör. I Thelander, E. Mot bättre vetande nya vägar till kunskap på arbetsplatsen. VINNOVA - rapport, VR 2008: 01.

Hultman, G. (1998). Spindlar i känsliga nätverk. Om skolans ledarskap och kunskapsbildning. Linköping, Skapande Vetande.

Hultman, G. (2001). Intelligenta Improvisationer. Lärares arbete och kunskapsbildning $i$ vardagen. Lund: Studentlitteratur.

Hultman, G. (2001b). Leading Cultures. A study of "acting in context" and the creation of meaning in work activities of principals. International Journal of Leadership in Education. Vol 4, No 2, pp. 137-148.

Hultman, G. (2004). Anställda i Förändring. Flämtande lågor, ambitioner och vardagsarbetet. En longitudinell fallstudie av förändringsprocesser $i$ små- och medelstora företag under sex år. Linköping: Skapande vetande.

Hultman, G. (2006). In-Between. Knowledge relations and use in context. I Wingård, B. (red). Livslång nyfikenhet. HLS Förlag. 
Hultman, G. (2008). Ambiguity as Work. Teachers' Knowledge Creation in Classrooms. NZ Journal of Teachers' Work. Vol. 5.

Hultman, G. (2011). Samspelet lärarstuderande - handledare. Den verksamhetsförlagda utbildningen. Pedagogisk forskning $i$ Sverige, årg 16, nr 2, s 118-137.

Hultman, G. (2015). Transformation, Interaktion eller Kunskapskonkurrens. Forskning om forskningsanvändning. Delrapport från SKOLFORSK. VR/UVK rapport. Under tryckning.

Hultman, G. \& Klasson, A. (1998). Paradoxes, Mini-worlds and Learning Processes: the dynamics of change in small companies. Studies in Continuing Education, Vol. 20, No. 1, pp. 51-69.

Hultman, G. \& Wedin, A-S. (2004). Ledarskap och lärande mellan politik och praktik. I Utbult, M. (red) Ledarskap i kommuner. Forskningsfrukter och tankeföda från chefsberättelser. Stockholm: Svenska Kommunförbundet.

Hultman, G. \& Wedin, A-S. (2014). Handledning och yrkeskunnande i komplexa miljöer. Skapandet av lärprocesser in-situ. I Kock, H. (Red.) Lärande i arbetslivet. Möjligheter och utmaningar. En vänbok till Per-Erik Ellström. Linköpings universitet: Karin Almlöfs förslag.

Kerr, S. \& Jermir, J. M. (1978). Substitutes for leadership: Their meaning and measurement. Organisational Behavior and Human Performance, 22, pp. 375-403.

Lindensjö, B. \& Lundgren, U. P. (1986). Politisk Styrning och Utbildningsreformer Stockholm: Liber Utbildningsförlaget.

Ludvigsson, A. (2009). Samproducerat ledarskap. Hur rektorer och lärare formar ledarskap $i$ skolans vardagsarbete. Högskolan i Jönköping, Diss. Nummer 7.

McLaughlin, M. W. (1998). Listening and Learning from the Field: Tales of Policy Implementation and Situated Practice. In Hargreaves et al (eds.) International Handbook of Educational Change. London: Kluwer Academics Publ., pp. 70-84.

Miller, R. J. \& Rowan, B. (2006). Effects of organic management on student achievement. American Educational Research Journal, Vol. 43, No. 2, PP. 219-253.

Mintzberg, H. (1973). The Nature of Managerial Work .New York: Harper \& Row, Publ.

Moqvist, L. (2005). Ledarskap $i$ vardagsarbetet - en studie av högre chefer $i$ statsförvaltningen. Diss. Linköping Studies in Education and psychology No. 100. Linköpings universitet.

Nespor, J. (1994). Knowledge in Motion: Space, Time and Curriculum in Undergraduate Physics and Management. London: The Falmer Press.

Nespor, J. (1997). Tangled up in school: politics, Space, Bodies, and Signs in the Educational process. Mahwah, New Jersey: Lawrence Erlbaum Ass., Publ.

Nihlfors, E. (2003). Skolchefen i skolans styrning och ledning. Uppsala Studies in Education

102. Diss. Uppsala universitet.

Ogawa, R. T., Crain, R., Loomis, M. \& Ball, T. (2008). CHAT-IT: Toward Conceptualizing Learning in the Context of Formal Organizations. Educational Researcher, Vol. 37, No. 2, pp. 83-95.

Peterson, K. D. (1984). Mechanisms of Administrative Control over Managers in Educational Organizations, Administrative Science Quarterly, Vol.29, pp. 573-597.

Pitner, N.J. (1982). Training of the School Administrator: State of the Art. Occ. Paper. Eugene: University of Oregon.

Powell, W. P. \& DiMaggio, P. J. (Eds.) (1991). The New Institutionalism in Organizational Analysis. Chicago: The University of Chicago Press.

Pitner, N.J. \& Ogawa, R.T. (1981). Organizational Leadership: The Case of the School Superintendent, Educational Administration Quarterly, Vol.17. No.2, pp. 45-65.

Robertson, J. \& Timperley, H. (Eds.) 2011. Leadership and learning. London: SAGE. 
Sahlin Andersson, K. (1999). I mötet mellan reform och praktik. I Zeuthen Bentsen, E., Borum, F., Erlingsdottir, G. \& Sahlin-Andersson, K. (red.) Når styrningsambitioner möder praxis. Köpenhamn: Handelshögskolens Forlag.

Seashore Louis, K. (2010). Better schools through better knowledge? New understanding, new uncertainty. In Hargreaves, A. et al. (eds). Second International Handbook of Educational Change, London: Springer International Handbooks of Education 23, pp. 3-28.

Siskin, L. S. (1994). Realms of Knowledge. Academic Departments in Secondary Schools. Washington, D. C.: The Falmer Press.

Spillane, J.P. (2006). Distributed leadership. San Francisco, Jossey-Bass.

Spillande, J.P, Healey, K., Parise, L. M. \& Kenney, A. (2011). A Distributed Perspective on Learning Leadership. In Robertson, J. \& Timperley, H. (Eds.) Leadership and learning. London: SAGE.

Strömberg, U-B. \& Tydén, T. (1999). Spännande möten. Samverkan mellan forskare och praktiker. Stockholm: Svenska Kommunförbundet.

Thomson, P. (2009). School leadership. Heads on the block? London: Routledge.

Thrupp, M. (1999). Schools making a difference. Let's be realistic! Buckingham: Open university press.

Wedin, A-S. (2007). Lärares arbete och kunskapsbildning. Utmaningar och inviter $i$ den vardagliga praktiken. Linköping Studies in Pedagogic Practices, No. 2, Linköpings universitet.

Weick, K. E. (1995). Sensemaking in Organizations. Thousand Oaks: SAGE Publ.

Willis, Q. (1980). The Work Activity of School Principals: An Observational Study. The Journal of Educational Administration, Vol. 18. No. 1, pp. 27-54.

Yukl, G. A. (1989/2013) Leadership in Organizations. Second edition. Englewood Cliffs, New Jersey: Prentice-Hall Int., Inc.

Yukl, G. A. (2009). Leading organizational learning: reflections on theory and research. The Leadership Quarterly. 20, pp. 49-53. 